\title{
Ketimpangan Ekonomi Berdampak pada Tingkat Kriminalitas? Telaah dalam Perspektif Psikologi Problematika Sosial
}

\author{
Agung Minto Wahyu ${ }^{*}$, Panji Galih Anugrah ${ }^{1}$, Achmad Muhammad Danyalin ${ }^{1}$ \\ Rakhmaditya Dewi Noorrizki ${ }^{1}$
}

${ }^{1}$ Universitas Negeri Malang, Indonesia

\author{
A R T I C L E I N F O \\ Article history: \\ Received 12 June 2021 \\ Accepted 03 November \\ 2021 \\ Available online 01 \\ December 2021 \\ Kata Kunci: \\ Ketimpangan Ekonomi; \\ Kriminalitas; Problematika \\ Sosial; Perspektif \\ Fungsionalisme; Perspektif \\ Konflik \\ Keywords: \\ Economic Inequality; \\ Criminality; Social \\ Problems; Functionalism \\ Perspective; Conflict \\ Perspective
}

\begin{abstract}
A B S T R A K
Ketimpangan ekonomi merupakan salah satu fenomena yang dapat menjadi permasalahan sosial. Kriminalitas adalah salah satunya. Tujuan dalam penelitian ini adalah mengkaji pengaruh ketimpangan ekonomi terhadap munculnya kriminalitas dari perspektif fungsionalisme, pengaruh ketimpangan ekonomi terhadap munculnya kriminalitas dari perspektif konflik dan menemukan solusi berbasis teori problematika sosial yang dapat digunakan untuk menurunkan ketimpangan ekonomi yang menjadi pemicu kriminalitas. Metode yang digunakan adalah narrative review yang merangkum berbagai hasil penelitian dan mengomparasikannya satu sama lain sehingga dapat menghasilkan interpretasi holistik. Literatur yang telah terkumpul diinterpretasi dalam bentuk naratif dengan mengelompokkan data hasil ekstraksi yang sejenis untuk menjawab tujuan penelitian. Hasil penelitian menunjukkan bahwa perspektif fungsionalisme melihat bahwa ketimpangan ekonomi yang berdampak pada kriminalitas disebabkan oleh ketidakmampuan setiap elemen dalam menjalankan fungsinya. Perspektif konflik melihat bahwa ketimpangan ekonomi yang berdampak pada kriminalitas disebabkan oleh ketidakmampuan masyarakat menengah
\end{abstract} bawah dalam memenuhi sumber daya dalam hidupnya. Dari sudut pandang fungsionalis, solusi untuk ketimpangan ekonomi adalah memaksimalkan kembali fungsi elemen masyarakat yang berperan dalam kegiatan ekonomi. sedangkan dari sudut pandang konflik, solusinya adalah para pemilik modal menambah jumlah anggaran dana untuk CSR. Dapat disimpulkan bahwa perspektif fungsionalisme dan konflik mendukung bahwa ketimpangan ekonomi dapat berdampak pada kriminalitas.

\section{A B S T R A C T}

Economic inequality is a phenomenon that can become a social problem. A crime is one of the social problems from economic inequality. The study objectives are to examine the effect of economic inequality on the emergence of crime from the perspective of functionalism, the effect of economic inequality on the emergence of crime from a conflict perspective, and find solutions based on the theory of social problems that can be used to reduce economic inequality that triggers crime. The method used is a narrative review that summarizes various research results and compares them to produce a holistic interpretation. The literature that has been collected is interpreted in the form of a narrative by grouping similar extracted data to answer the research objectives. The results showed that the functionalism perspective saw that economic inequality that impacted crime was caused by the inability of each element to carry out its functions. The conflict perspective sees that economic inequality that impacts crime is caused by the inability of the lower middle class to fulfill the resources of their life. From a functionalist point of view, the solution to economic inequality is to maximize the function of elements of society that play a role in economic activity. Whereas from the conflict point of view, the solution is for the owners of capital to increase the amount of their budget for CSR. It can be concluded that the perspective of functionalism and conflict supports that economic inequality can impact crime.

\footnotetext{
* Corresponding author.

E-mail addresses: agungminto98@gmail.com
} 



\section{Pendahuluan}

Ketimpangan atau disparitas ekonomi dalam sebuah negara wajar terjadi selama dalam batas yang normal (Anwar dkk., 2019). Tingkat ketimpangan ekonomi diukur dengan menggunakan indeks rasio gini yang bernilai antara 0 hingga 1 . Nilai 0 menunjukkan tingkat pemerataan ekonomi yang sempurna, sedangkan nilai 1 menunjukkan tingkat ketimpangan yang sempurna (DPR-RI, 2019). Terdapat tiga kriteria yang digunakan untuk menilai tingkat ketimpangan suatu negara, yaitu nilai indeks gini rasio $<0,35$ menunjukkan ketimpangan rendah, 0,35-0,5 menunjukkan ketimpangan sedang, dan > 0,5 menunjukkan ketimpangan tinggi (Utami, 2020).

Data menunjukkan bahwa angka indeks rasio gini di Indonesia sejak tahun 2015-2019 terus mengalami tren penurunan (BPS, 2020a). Sejalan dengan hal tersebut, tingkat kriminalitas di Indonesia dalam kurun waktu yang sama juga mengalami penurunan (BPS, 2018; BPS, 2019; BPS, 2020b). Meskipun menurun, rasio gini nasional di Indonesia dalam kurun waktu tersebut berada pada rentang indeks 0,35 hingga 0,5 sehingga masih tergolong dalam kategori ketimpangan yang sedang/moderat. Berikut adalah data lengkap perbandingan antara indeks rasio gini dan tingkat kriminalitas dalam kurun waktu 2015-2019.

Tabel 1.

Perbandingan antara Rasio Gini dan Tingkat Kriminalitas selama Tahun 2015-2019

\begin{tabular}{|c|c|c|c|}
\hline Tahun & Semester & Rasio Gini & Tingkat Kriminalitas \\
\hline \multirow[t]{2}{*}{2015} & 1 & 0,408 & \multirow{2}{*}{$\begin{array}{l}140 \text { orang/100 } \\
\text { penduduk }\end{array}$} \\
\hline & 2 & 0,402 & \\
\hline \multirow[t]{2}{*}{2016} & 1 & 0,397 & \multirow{2}{*}{$\begin{array}{l}140 \text { orang/100 } \\
\text { penduduk }\end{array}$} \\
\hline & 2 & 0,394 & \\
\hline \multirow[t]{2}{*}{2017} & 1 & 0,393 & \multirow{2}{*}{$\begin{array}{l}129 \text { orang/100 } \\
\text { penduduk }\end{array}$} \\
\hline & 2 & 0,391 & \\
\hline \multirow[t]{2}{*}{2018} & 1 & 0,389 & \multirow{2}{*}{$\begin{array}{l}113 \text { orang/100 } \\
\text { penduduk }\end{array}$} \\
\hline & 2 & 0,384 & \\
\hline 2019 & - & 0,380 & $\begin{array}{l}103 \text { orang/100 } \\
\text { penduduk }\end{array}$ \\
\hline
\end{tabular}

Sumber: Diolah dari BPS (2020)

Berdasarkan Tabel 1 tersebut, terlihat bahwa tingkat kriminalitas di Indonesia memiliki tren penurunan yang konsisten dari tahun 2016 hingga 2019. Pada 2019 menjadi tahun dengan tingkat kriminalitas terendah dengan melibatkan korban kejahatan sebanyak 1,01 persen dari total penduduk Indonesia (BPS, 2020b). Kriminalitas sendiri didefinisikan sebagai perbuatan yang dapat merugikan orang lain sehingga bertentangan dengan moral kemanusiaan, serta melanggar hukum dan undang-undang pidana (Sari, Hasyim, \& Nurmalisa, 2015). Kejahatan dapat muncul karena adanya hasil interaksi antar fenomena yang saling mempengaruhi (Gosita, 2004).

Pada semester 1 tahun 2020, angka indeks rasio gini di Indonesia mengalami sedikit peningkatan dari 0,080 menjadi 0,081 (BPS, 2020b). Bahkan, adanya pandemi yang berdampak pada kegiatan ekonomi selama tahun 2020 ini membuat banyak pihak memprediksi jika ketimpangan ekonomi pada semester 2 tahun 2020 akan semakin melebar (Anwar, 2020; Putra, 2020). Sejalan dengan peningkatan ketimpangan ekonomi tersebut, Kepolisian RI (dalam Koran Tempo, 2020) memaparkan bahwa pada Juli 2020 telah terjadi peningkatan kriminalitas dari 5.282 kasus menjadi 5.656 kasus atau sebesar 7,08 persen. Pada Agustus 2020 juga meningkat sebesar 4,49 persen dari 4.449 kasus menjadi 4.649 kasus.

Adanya ketimpangan ekonomi tersebut dapat berdampak secara langsung maupun tidak langsung terhadap tingkat kriminalitas (Bourguignon, 2001). Becker (1968) menyatakan bahwa seseorang akan melakukan tindakan kriminalitas ketika income yang diperoleh dari kegiatan tersebut lebih besar dibanding income yang didapatkan dari kegiatan ekonomi yang legal. Terdapat berbagai hasil penelitian yang membuktikan bahwa adanya ketimpangan ekonomi dapat berdampak pada terjadinya kriminalitas. Penelitian-penelitian tersebut diantaranya telah 
dilakukan oleh Arisna (2020); Masfiatun (2019); Hardiawan (2018); Aulia (2014); Herpandi (2017); Satriananta (2016); Harahap (2014); Hendri (2014); Hairani dan Syahputri (2016). Keseluruhan hasil penelitian tersebut menunjukkan bahwa ketimpangan ekonomi berpengaruh secara positif dan signifikan terhadap kemunculan kriminalitas.

Bertolak belakang dengan hasil penelitian di atas, terdapat penelitian lain yang menunjukkan hasil berbeda. Penelitian tersebut dilakukan oleh Mardianysah \& Sukartini (2020) dan Rina (2019) yang mendapatkan hasil bahwa ketimpangan ekonomi berpengaruh secara tidak signifikan terhadap kriminalitas. Bahkan hasil penelitian Rina (2019) memiliki kecenderungan bahwa ketimpangan ekonomi berpengaruh negatif terhadap kriminalitas.

Telaah dari hasil penelitian yang telah dilakukan tersebut menunjukkan bahwa belum ada penelitian lain terkait pengaruh ketimpangan ekonomi terhadap kriminalitas yang secara spesifik mengkaji menggunakan perspektif teori problematika sosial. Teori problematika sosial tersebut dapat menjawab dari sudut pandang yang berbeda sehingga dimungkinkan untuk menghasilkan solusi yang baru untuk mengatasi permasalahan tersebut. Sullivan (2016) menjelaskan bahwa teori problematika sosial yang relevan digunakan untuk mengkaji permasalahan ini yaitu perspektif fungsionalisme dan perspektif konflik.

Perspektif fungsionalisme memandang bahwa kelompok sosial yang beranggotakan individu, kelompok, atau organ telah dibentuk oleh lingkungannya sebagai agen sosial yang memiliki fungsi dan peran tertentu dalam masyarakat. Masalah akan muncul ketika ada elemen yang mengalami disfungsi atau tidak mampu menjalankan fungsi dan perannya dengan baik. Di sisi lain, perspektif konflik memandang bahwa di dalam tatanan masyarakat terdapat individu, kelompok, atau organ yang saling berkompetisi untuk mendapatkan sumber daya yang terbatas. Apabila terdapat pihak yang kalah berkompetisi dan gagal untuk mendapatkan sumber daya tersebut maka akan menjadi permasalahan sosial. Kegagalan juga dipengaruhi oleh minimnya kekuatan yang dimiliki oleh pihak tersebut (Leon-Guerrero, 2019).

Berdasarkan paparan latar belakang tersebut, dapat disimpulkan bahwa masih terdapat hasil penelitian yang tidak konsisten antara pengaruh ketimpangan ekonomi terhadap kriminalitas. Hasil yang tidak konsisten membuat penelitian terkait fenomena tersebut perlu untuk dikaji kembali. Di samping itu, belum adanya penelitian lain yang melihat fenomena tersebut dari sudut pandang teori problematika sosial juga membuatnya perlu dikaji lebih mendalam.

Adapun tujuan dalam penelitian ini adalah a) mengkaji pengaruh ketimpangan ekonomi terhadap munculnya kriminalitas dari perspektif fungsionalisme; b) mengkaji pengaruh ketimpangan ekonomi terhadap munculnya kriminalitas dari perspektif konflik; c) menemukan solusi berbasis teori problematika sosial yang dapat digunakan untuk menurunkan ketimpangan ekonomi yang menjadi pemicu kriminalitas.

Manfaat yang diharapkan dari hasil penelitian ini adalah a) secara teoritis dapat menjadi rujukan bagi peneliti selanjutnya yang akan melakukan penelitian mengenai pengaruh ketimpangan ekonomi terhadap kriminalitas; b) secara praktis bagi pemerintah dapat menjadi pertimbangan dalam membuat kebijakan. Sedangkan bagi masyarakat yang menjadi objek, dapat menjadi acuan dalam melakukan introspeksi dan perbaikan dalam sesuai solusi.

\section{Metode}

Jenis penelitian yang digunakan dalam penelitian ini adalah narrative review. Narrative review merupakan kajian yang merangkum berbagai hasil penelitian dan membandingkannya satu sama lain sehingga menghasilkan interpretasi yang holistik. Oleh karena itu, dalam melakukan narrative review, perlu ditetapkan secara eksplisit kriteria pencarian literatur dan kriteria inklusi. Salah satu cara terbaik untuk melakukan narrative review pada literatur adalah dengan mendeskripsikan secara singkat hasil utama berdasarkan tingkat kekuatan bukti, ruang lingkup penelitian, dan relevansi dengan topik penelitian (Gasparyan dkk., 2011).

Penelitian narrative review dimulai dengan menentukan topik dan ruang lingkup yang akan menjadi fokus penelitian sehingga dapat merumuskan judul penelitian. Penulis juga harus mampu mendeskripsikan urgensi dan kebaruan topik penelitian yang ingin diteliti. Selanjutnya penulis dapat menentukan rumusan masalah dan tujuan yang ingin dicapai. Hasilnya yaitu topik 
yang diangkat dalam penelitian ini adalah ketimpangan atau kesenjangan ekonomi dan tingkat kriminalitas. Tahap kedua adalah melakukan proses pencarian literatur dengan menggunakan kata kunci yang relevan dengan topik penelitian. literatur dapat dicari melalui berbagai sumber yang tersedia secara elektronik dan cetak. Setelah literatur terkumpul, kemudian dilakukan proses pemilihan literatur untuk mempermudah proses analisis. Database dan kata kunci dalam pencarian literatur telah tergambar dalam Tabel 2. Tahap ketiga adalah menulis. Proses penulisan dimulai dengan menggabungkan poin-poin informasi dari berbagai literatur menjadi satu kesatuan yang utuh. Poin-poin informasi tersebut kemudian dideskripsikan secara lebih mendalam untuk penelitian selanjutnya sekaligus menjawab kebutuhan praktis. Setelah itu, langkah selanjutnya adalah menemukan poin-poin baru berbasis bukti yang dapat menjadi temuan analisis. Penulis juga wajib mencantumkan berbagai sumber pustaka yang pernah digunakan dalam daftar referensi.

Pengumpulan literatur dalam penelitian ini dilakukan Desember 2020 hingga Februari 2021. Pencarian dilakukan menggunakan pada berbagai database seperti, Google Scholar. Kata kunci yang digunakan 1) kesenjangan ekonomi; 2) kriminalitas; 3) kesenjangan ekonomi terhadap kriminalitas; 4) perspektif sosiologi dalam memandang problematika ekonomi; 5) narrative review method. Kriteria yang ditetapkan untuk melakukan seleksi literatur adalah artikel yang ditulis secara ilmiah dan relevan dengan topik penelitian, artikel dapat diakses secara lengkap, dan artikel diprioritaskan paling terbaru. Berikut adalah selengkapnya.

Tabel 2.

Kriteria Pengumpulan Literatur

Mesin Pencarian Kata Kunci

1. Google Scholar

2. Sinta

3. Google News

4. Sciencedirect
1. Kesenjangan ekonomi

2. Kriminalitas

3. Kesenjangan ekonomi terhadap kriminalitas

4. Prespektif sosiologi dalam memandang problematika ekonomi

5. Narrative review method

Literatur yang telah terkumpul disintesis secara naratif dengan mengelompokkan data hasil ekstraksi yang sejenis untuk menjawab tujuan penelitian. Analisis isi literatur dilakukan dengan koding berdasarkan substansi inti atau garis besar yang diuraikan dalam sebuah kalimat, kemudian dilakukan pencarian persamaan dan perbedaan pada literatur sehingga dapat menjadi sebuah kesimpulan.

\section{Hasil dan Pembahasan}

Menurut perspektif fungsionalis, masyarakat terdiri dari elemen-elemen yang saling berkaitan dan bekerja sama untuk mencapai sebuah tujuan. Masing-masing elemen memiliki fungsi yang berbeda yang saling berkaitan dalam proses mencapai sebuah tujuan. Jika salah satu elemen gagal dalam menjalankan fungsinya, maka akan menyebabkan ketidakseimbangan dalam masyarakat yang berpotensi memicu munculnya problematika sosial (Sullivan, 2016).

Perspektif fungsionalis memandang permasalahan ketimpangan ekonomi yang terjadi di masyarakat sebagai akibat dari adanya elemen masyarakat yang tidak berfungsi sebagaimana mestinya. Elemen masyarakat yang terlibat dalam kegiatan ekonomi diantaranya yaitu pemerintah, pemilik usaha, dan para pekerja. Elemen-elemen tersebut memiliki fungsi masingmasing dan saling bekerjasama untuk mencapai kesejahteraan ekonomi (Leon-Guerrero, 2019). Ketimpangan ekonomi yang terjadi di Indonesia, menurut Ebel dan Yilmaz (2002), dipengaruhi oleh pertumbuhan ekonomi, investasi, indeks pembangunan manusia (IPM), dan produktivitas tenaga kerja. Tingkat produktivitas tenaga kerja yang berbeda antara satu daerah dengan yang lainnya dapat memperlebar ketimpangan ekonomi. Hasil penelitian yang dilakukan oleh Putri, dkk. (2015) menyatakan bahwa pada tahun 2010 terjadi penurunan produktivitas pekerja di Kalimantan. Menurut hasil penelitian Amin (2014) menyatakan bahwa pekerja di Sulawesi Utara 
justru mengalami peningkatan produktivitas dalam kurun tahun 2008-2012. Jika ditinjau dengan apa yang disampaikan Ebel dan Yilmaz (2002), perbedaan tingkat produktivitas tenaga kerja di dua daerah tersebut akan menyebabkan semakin meningkatnya ketimpangan ekonomi. Ketika ditarik benang merah dari fenomena ini, maka ketimpangan ekonomi yang terjadi disebabkan karena gagalnya tenaga kerja untuk menajalankan fungsinya secara maksimal.

Data tingkat kriminalitas yang dilaporkan oleh BPS, pada tahun 2010, di Kalimantan mengalami peningkatan angka kriminalitas dari yang sebelumnya sebanyak 7.180 kasus menjadi 10.007 kasus. Berdasarkan data tersebut dapat dipahami bahwa peningkatan ketimpangan ekonomi masyarakat Kalimantan diikuti dengan peningkatan tingkat kriminalitas. Oleh karena itu dapat disimpulkan bahwa peningkatan kesenjangan ekonomi dapat menjadi salah satu factor penyebab semakin bertambahnya tingkat kejahatan.

Disamping karena belum optimalnya tenaga kerja dalam menjalankan fungsinya, ketimpangan ekonomi juga dapat disebabkan karena minimnya ketersediaan lapangan pekerjaan (Adelman \& Morris, 1973). Safutra (2020) menyatakan bahwa minimnya lapangan pekerjaan yang tersedia berdampak pada tingginya tingkat pengangguran di Indonesia. Berdasarkan data Badan Pusat Statistik BPS angka pengangguran di Indonesai sampai Februari 2020 mencapai 6,88 juta orang. Permasalahan pengangguran nasional merupakan salah satu tanggung jawab pemerintah (Pigai, 2019). Untuk itu, ketimpangan ekonomi juga dapat disebabkan karena ketidak maksimalan pemerintah menjalankan fungsinya dalam menyediakan lapangan pekerjaan.

Sjafrizal (2012) juga menyatakan bahwa ketimpangan ekonomi juga dapat disebabkan karena adanya konsentrasi kegiatan ekonomi di wilayah-wilayah tertentu. Pertumbuhan ekonomi akan cenderung lebih cepat pada daerah yang menjadi tempat konsentrasi kegiatan ekonomi. Kondisi ini yang akan mendorong meningkatnya kesenjangan ekonomi.

Ditinjau dari Undang-Undang Nomor 32 tahun 2004, pemerintah membuat kebijakan mengenai pergeseran dalam pembangunan ekonomi yang awalnya sentralis menjadi desentralis. Namun, kenyataan di lapangan masih banyak ditemukan adanya sentralisasi kegiatan ekonomi. Contoh kasus yang terjadi misalnya di Pasuruan, kegiatan ekonomi di daerah tersebut sebagian besar masih terpusat di wiliayah bagian barat. Hal ini menyebabkan timbulnya ketimpangan ekonomi antara masyarakat yang tinggal di wilayah barat dan timur, oleh karena itu ketimpangan ekonomi yang terjadi di Pasuruan menjadi salah satu penyebab meningkatnya tingkat kriminalitas, seperti pencurian dengan kekerasan (curas), pembegalan, dan perampokan (Muslim dan Ahwan, 2018). Didukung data yang menunjukkan telah terjadi 73 kasus pembegalan di wilayah hukum Polres Kota Pasuruan bahwa selama tahun 2019 (Warta Bromo, 2019), dan 57 kasus pembegalan di wilayah hukum Polres Kabupaten Pasuruan (Arifin, 2019). Diperkuat dari hasil wawancara dengan Kepala Pembina Narapidana di Jawa Timur menyatakan bahwa jumlah narapidana kasus pembegalan di Lapas Kelas IIB Pasuruan menjadi yang tertinggi di Jawa Timur.

Peningkatan ketimpangan ekonomi karena belum optimalnya fungsi elemen masyarakat dapat menyebabkan peningkatan kriminalitas. Menurut Reksohadiprojo \& Karseno (1985) kejahatan atau kriminalitas pada hakikatnya terjadi karena adanya elemen-elemen masyarakat yang tidak menjalankan fungsinya secara maksmial. Oleh karena itu, masyarakat memiliki melakukan kriminalitas sebagai upaya untuk mempertahankan hidup.

Berbeda dengan perspektif fungsionalis, perspektif konflik memandang ketimpangan ekonomi sebagai suatu hal yang wajar, bukan sebagai suatu permasalahan. Karena perspektif konflik memandang bahwa masyarakat terdiri dari berbagai kelompok kepentingan berbeda yang saling berkompetisi untuk mendapatkan sumberdaya yang ada. Dalam hal ini adalah ekonomi. Adanya konflik kepentingan dalam kegiatan ekonomi justru menjadi ciri khas dalam masyarakat (Sullivan, 2016). Permasalahan terjadi, menurut perspektif konflik, ketika kelompok-kelompok yang berkuasa merasa bahwa telah terjadi ketidakadilan dalam pendistribusian sumberdaya. Sehingga, terkadang, kelompok berkuasa saling bekerjasama untuk mendapatkan lebih banyak lagi sumberdaya yang ada (Sullivan, 2016).

Fenomena ketimpangan ekonomi, sesuai dengan perspektif konflik, dapat terlihat pada apa yang terjadi di Yogyakarta pada tahun 2019 menunjukan bahwa indeks gini mencapai 0,423. Hal ini dikonformasi oleh BPPD D. I Yogyakarta yang menyatakan kondisi tersebut terjadi karena adanya ketidak merataan persebaran pendapatan antara masyarakat kaya dan miskin (BPS, 
2019). Fenomena serupa juga terjadi di Papua dari data yang di rilis Word Bank (2019), Papua menjadi daerah dengan tingkat kemiskinan tertinggi di Indonesia di mana sebanyak 27 persen masyarakatnya berada di bawah garis kemiskinan. Hal ini berbanding terbalik dengan kondisi para pimpinan yang ada di PT. Freeport, Papua yang gajinya mencapai ratusan juta per bulan (Charisma, 2017). Hal itu terbukti membuat Papua masih menduduki posisi 5 besar provinsi dengan ketimpangan ekonomi tertinggi di Indonesia dengan indeks rasio gini sebesar 0,397 (BPS, 2020c).

Dalam konteks nasional, ketimpagan ekonomi juga terjadi. Menurut Direktur Eksekutif Megawati Institute, Arif Budimanta (dalam Hamdani, 2017), 45 persen kekayaan nasional hanya dikuasai oleh 1 persen penduduk. Sedangkan 55 persen sisanya dimiliki oleh 99 persen penduduk Indonesia. Hal ini jelas merupakan bukti ketimpangan ekonomi karena kekayaan nasional hanya dikuasai sebagian kecil penduduk. Hal itu menimbulkan kecemburuan sosial dari kaum menengah ke bawah kepada kaum menengah ke atas (Bappenas, 2017).

Kelly (2000) menyatakan bahwa ketimpangan ekonomi menyebabkan timbulnya peluang terhadap aksi kriminalitas. Hal ini dibuktikan dengan data kriminalitas di Kota Medan mulai tahun 2000-2017 yang mengalami peningkatan signifikan. Herpandi (2017) menyatakan bahwa meningkatnya angka kriminalitas di Medan disebabkan karena tingginya ketimpangan ekonomi yang terjadi.

Penelitian Efendi (2021) juga menyebutkan bahwa selama 2014-2019 di pulau Jawa mengalami peningkatan tingkat kriminalitas dimana ketimpangan ekonomi menjadi faktor utama dibandingkan faktor lain seperti pengangguran dan pendidikan. Selain itu, Septaria (2021) juga menyebutkan bahwa adanya ketimpangan Ekonomi di Kota Banjarmasin berpengaruh signifikan dalam menambah angka kriminalitas yang terjadi.

Solusi berbasis perspektif fungsionalis bagi permasalahan ketimpangan ekonomi yaitu dengan memaksimalkan kembali fungsi elemen-elemen masyarakat yang terkait dengan kegiatan perekonomian (Lybbert dan Wydick, 2017). Pemerintah diharapkan mampu membuka lapangan pekerjaan yang lebih banyak agar dapat menekan angka pengangguran. Selain itu pemerintah juga diharapkan lebih giat dalam mengupayakan desentralisasi kegiatan ekonomi. (Holden dan Sparrman, 2018)

Solusi berdasarkan perspektif konflik bagi permasalahan ketimpangan ekonomi yang dapat digunakan adalah para pemilik perusahaan besar mengalokasikan lebih banyak dana untuk corporate social responsibility (CSR). Para pemilik perusahaan besar dapat menggunakan dana CSR tersebut untuk memberikan bantuan kepada masyarakat yang tingkat ekonominya rendah atau memberikan beasiswa kepada anak-anak yang memiliki potensi, tetapi berasal dari keluarga kurang mampu. Hal itu dapat menjadi sarana untuk mendistribusikan aset dari masyarakat menengah atas untuk masyarakat menengah ke bawah (Barnett dkk., 2020).

\section{Simpulan dan Saran}

Berdasarkan hasil penelitian diatas dapat disimpulkan bahwa a) ketimpangan ekonomi berdasarkan sudut pandang fungsionalis disebabkan karena adanya elemen masyarakat yang tidak menjalankan fungsinya secara maksimal. b) Selain itu ketimpangan ekonomi dipandang dari sudut pandang konflik bahwasanya ketimpangan bukanlah problematika sosial, hal ini dikarenakan dalam masyarakat terdapat kelompok kepentingan yang berbeda dan saling memperebutkan sumber daya yang ada. c) Solusi yang dapat diterapkan pada fenomena ini adalah yang pertama pemerintah dapat mendorong elemen masyarakat untuk meningkatkan fungsinya di masyarakat. Selain itu bagi para pemilik modal dapat membagikan sebagian hartanya untuk pembiayaan pendidikan dan bantuan sosial bagi masyarakat kurang mampu yang ada di sekitarnya.

\section{Daftar Rujukan}

Adelman, I., \& Morris, C. T. (1973). Economic Growth and Social Equity in Developing Countries. California: Stanford University Press.

Amin, R. M. (2014). Tingkat Produktivitas Tenaga Kerja Sektor Pertanian di Provinsi Sulawesi Utara. Skripsi. Manado: Universitas Sam Ratulangi. 
Anwar, M. (2020). Asimilasi dan Peningkatan Kriminalitas Di Tengah Pembatasan Sosial Berskala Besar Pandemi Corona. 'Adalah: Buletin Hukum dan Keadilan, 4(1), 497-513.

Anwar, M. H., Ramadani, M. J., Utomo, G. P., Murnawi, F. F., Rozi, A. H., \& Vionilla, K. (2019). Analisis Ketimpangan Perekonomian terhadap Tingkat Pendidikan di Kecamatan Prambanan. Jurnal Geografi, Edukasi dan Lingkungan(JGEL), 3(1), 26-33.

Arifin, M. (2019). Satu Anggota Komplotan "Kampung Begal" di Pasuruan Tertangkap, detik.news. (Online), (URL: https://news.detik.com/berita-jawa-timur/d-4714349/satu-anggotakomplotan-kampung-begal-di-pasuruan-tertangkap), Diakses tanggal 20 Oktober 2021.

Arisna, P. (2020). Analisis Pengaruh Tingkat Pengangguran Terhadap Tingkat Kriminalitas Properti di Indonesia Tahun 2013-2017. Tesis. Bandung: Universitas Padjadjaran.

Aulia, S. (2014). Hubungan Ketimpangan Pendapatan dan Kriminalitas: Sebuah Studi Literatur. Skripsi. Bandung: Universitas Padjadjaran.

Bappenas. (2017). Prakarsa Pemerintah Daerah Dalam Upaya Pengurangan Kesenjangan Wilayah dan Pembangunan Daerah. Jakarta: Kementerian Perencanaan Pembangunan Nasional/Badan Perencanaan Pembangunan Nasional.

Barnett, M. L., Henriques, I., \& Husted, B. W. (2020). Beyond Good Intentions: Designing CSR Initiatives for Greater Social Impact. Journal of Management, 20(10), 1-28.

Becker, G. (1968). Crime and Punishment: An Economic Approach. Journal of Political Economy, $76,169-217$.

Bourguignon, F. (2001). Crime as a Social Cost of Poverty and Inequality: A Review Focusing on Developing Countries. World Bank Discussion Paper.

BPS. (2018). Statistik Kriminal Tahun 2018. Jakarta.

BPS. (2019). Statistik Kriminal Tahun 2019. Jakarta.

BPS. (2020a). Gini Ratio Provinsi 2012-2020. Jakarta.

BPS. (2020b). Statistik Kriminal Tahun 2020. Jakarta.

BPS. (2020c). Gini Ratio Menurut Provinsi dan Daerah 2020-2021. Jakarta

Charisma, S. (2017). Pengaruh Budaya Organisasi dan Kepuasan Kerja Terhadap Kinerja Pegawai Kontrak Balai Besar Wilayah Sungai Bengawan Solo. Tesis. Surakarta: Universitas Muhammadiyah Surakarta.

DPR-RI. (2019). Gini $\quad$ Ratio. (https://berkas.dpr.go.id/puskajianggaran/kamus/file/kamus-17.pdf), diakses pada 15 Maret 2021.

Ebel, R. D., \& Yilmaz, S. (2002). Concept of Fiscal Decentralization and World Wide Overview. (Online), (https://documents.worldbank.org/en/publication/documentsreports/documentdetail/716861468781761314/concept-of-fiscal-decentralization-andworldwide-overview), diakses pada 16 Maret 2021.

Effendi, A. I., Julia, A., \& Haviz, M. (2021). Faktor Ekonomi yang Mempengaruhi Kejahatan Properti di Pulau Jawa Tahun 2014-2019. Jurnal Riset Ilmu Ekonomi dan Bisnis, 1(1), 42-48.

Gasparyan, A. Y., Ayvazyan, L., Blackmore, H., \& Kitas, G. D. (2011). Writing a Narrative Biomedical Review: Considerations for Authors, Peer Reviewers, and Editors. Rheumatology International, 31, 1409-1417.

Gosita, A. (2004). Masalah Korban Kejahatan. Bandung: Raja Grafindo Persada.

Hairani, P., \& Syahputri, A. R. (2016). Analisis Ketimpangan Ekonomi dan Pengaruhnya terhadap Tingkat Kriminalitas di Propinsi Sumatera Utara. Ekonomikawan: Jurnal Ilmu Ekonomi dan Studi Pembangunan, 16(1), 56-76.

Hamdani, T. (2017). Arif Budimanta: 1\% Orang Terkaya RI Kuasai 45\% Kekayaan Nasional. Detik Finance. (Online), (https://finance.detik.com/berita-ekonomi-bisnis/d-3787540/arifbudimanta-1-orang-terkaya-ri-kuasai-45-kekayaan-nasional), diakses pada 16 Maret 2021.

Harahap, N. A. (2014). Analisis Faktor-Faktor yang Mempengaruhi Tingkat Kriminalitas di Sumatera Utara (Melalui Pendekatan Ekonomi). Tesis. Medan: Universitas Negeri Medan.

Hardiawan, D. (2018). Analisis Pengaruh Ketimpangan Pengeluaran dan Kondisi Sosioekonomi terhadap Tingkat Kriminalitas di Indonesia Periode 2015 dengan Pendekatan Spatial Econometrics dan Geographically Weighted Regression. Tesis. Bandung: Universitas Padjadjaran. 
Hendri, D. (2014). Kriminalitas: Sebuah Sisi Gelap dari Ketimpangan Distribusi Pendapatan. Jurnal Ekonomi dan Kebijakan Publik, 5(2), 1-19.

Herpandi, W. D. (2017). Pengaruh Ketimpangan Ekonomi terhadap Tingkat Kriminalitas di Kota Medan. Skripsi. Medan: Universitas Sumatera Utara.

Holden, S., \& Sparrman, V. (2018). Do Government Purchases Affect Unemployment? The Scandinavian Journal of Economics, 120(1), 124-158.

Kelly, M. (2000). Inequality and crime. Review of economics and Statistics, 82(4), 530-539.

Koran Tempo. (2020, September). Kriminalitas Meningkat selama Masa Pandemi. (Online), (https://koran.tempo.co/read/metro/457569/kriminalitas-meningkat-selama-masapandemi), diakses 16 Maret 2021.

Leon-Guerrero, A. (2019). Social Problems: Community, Policy, and Social Action. Unites States of America: Sage Publication.

Lybbert, T. J., \& Wydick, B. (2018). Poverty, Aspirations, and the Economics of Hope. Economic Development and Cultural Change, 66(4), 709-753.

Mardianysah, A. A., \& Sukartini, N. M. (2020). Ketimpangan Ekonomi, Kemiskinan dan Akses Informasi: Bagaimana Pengaruhnya terhadap Kriminalitas di Indonesia? Ekonika: Jurnal Ekonomi Universitas Kadiri, 5(1), 19-37.

Masfiatun. (2019). Pengaruh Faktor Ekonomi terhadap Jumlah Kejahatan (Crime Total) di Indonesia (2015-2017). Jurnal Keamanan Nasional, 5(2), 89-110.

Muslim, \& Ahwan, Z. (2018). Badmark Pasuruan "Kota Begal" Opposite Pemberitaan Prestasi Bupati Pasuruan (Analisis Wacana Kritis Teks Media Pemberitaan Begal dan Prestasi Bupati Pasuruan di www.Wartabromo.com Periode Oktober 2016 - Oktober 2017). Jurnal Heritage, 6(2), 1-7.

Pigai, N. (2019). Omnibus Law: Menciptakan Lapangan Kerja, Mengentaskan Pengangguran. Republik Merdeka. (Online), (https://rmol.id/read/2019/11/13/409986/omnibus-lawpengentasan-pengangguran-dan-penciptaan-lapangan-kerja), diakses pada 16 Maret 2021.

Putra, S. D. E. (2020). (Pand) Economics: Refleksi atas Sistem Ekonomi di Masa Pandemi Covid19. Jurnal PINUS: Jurnal Penelitian Inovasi Pembelajaran, 5(2), 17-29.

Putri, Y. E., Amar, S., \& Aimon, H. (2015). Analisis Faktor-Faktor yang Mempengaruhi Pertumbuhan Ekonomi dan Ketimpangan Pendapatan di Indonesia. Jurnal Kajian Ekonomi, $3(6)$.

Reksohadiprojo, S., \& Karseno, A. R. (1985). Ekonomi Perkotaan. Yogyakarta: BPFE.

Rina, A. (2019). Pengaruh Ketimpangan Ekonomi, Pengangguran, dan Kepadatan Penduduk terhadap Tingkat Kriminalitas di Indonesia. Skripsi. Padang: Universitas Andalas.

Safutra, I. (2020). Ketersediaan Lapangan Kerja Yang Minim Masih Menjadi PR Pemerintah. Jawa Pos. (Online), (https://www.jawapos.com/ekonomi/17/11/2020/ketersediaan-lapangankerja-yang-minim-masih-jadi-pr-pemerintah/), diakses pada 16 Maret 2021.

Sari, F. D., Hasyim, A., \& Nurmalisa, Y. (2015). Sikap Orang Tua terhadap Tindakan Kriminalitas Remaja di Desa Bumiratu. Jurnal Kultur Demokrasi, 4(2), 1-13.

Satriananta, A. K. (2016). Pengaruh Ketimpangan Ekonomi, pengangguran dan Kepadatan Penduduk terhadap Tingkat Kriminalitas di 31 Provinsi di Indonesia Periode 2009-2013. Skripsi. Bandung: Universitas Padjadjaran.

Septaria, R., \& Zulfaridatulyaqin, S. M. (2021). Tingkat Kriminalitas di Kota Banjarmasin dengan Pendekatan Ekonomi. JIEP: Jurnal Ilmu Ekonomi dan Pembangunan, 4(1), 50-64.

Sjafrizal. (2012). Ekonomi Wilayah dan Perkotaan. Jakarta: Raja Grafindo Persada.

Sullivan, T. J. (2016). Introduction to Social Problems. United States: Pearson Education, Inc.

Utami, R. B. (2020). Analisis Pengaruh Angka Beban Ketergantungan, Kepadatan Penduduk, Garis Kemiskinan terhadap Indeks Gini di Indonesia. edical Technology and Public Health Journal (MTPH Journal), 4(2), 2549-2993.

Warta Bromo. (2019). Curanmor Dominasi Catatan Kriminal di Kota Pasuruan Selama 2019. (Online), (URL: https://www.wartabromo.com/2019/12/28/curanmor-dominasicatatan-kriminal-di-kota-pasuruan-selama-2019/). Diakses tanggal 21 Oktober 2021. 
World Bank. (2019). East Asia and Pacific Economic Update October 2019: Weathering Growing Risk. (Online), (https://openknowledge.worldbank.org/handle/10986/32482), diakses pada 15 Maret 2021 